\title{
Market Delineation Study of the Fish Market in Nigeria: An Application of Cointegration Analysis
}

\author{
Teslim Bada \\ Department of Economics, University of Portsmouth, UK \\ E-mail: tesbom@yahoo.com \\ M.A.Y. Rahji (Corresponding author) \\ Department of Agricultural Economics, University of Ibadan, Nigeria \\ E-mail: mayrahji@yahoo.com
}

\begin{abstract}
In Nigeria aquaculture has provided an avenue to bridge the ever-widening demand and supply gap in fish. It uses land resources that would have otherwise been a waste. This paper examined whether Catfish is in the same market with Hake, Mackerel and Sadinnela. Unit root tests, Johansen`s bivariate and multivariate co integration analyses were carried out. The analyses show that there is co integration among the species.. The hypothesis of no substitution between Catfish and the imported species was rejected All the species were classified as being in the same market and are close substitutes. The results indicate that the price of catfish is not insulated from the prices of the imported species. The prices of the imported species are however insulated from the price of the local species. Fish production policies designed to alter fish prices without taking into account the foreign prices are not likely to be effective in Nigeria.
\end{abstract}

Keywords: Market delineation, Fish market, Bivariate, Multivariate analysis, Nigeria

\section{Introduction}

Aquaculture is still a subsistence activity in Africa. Some $30 \%$ of global fish supplies come from aquaculture but Africa produces less than $0.2 \%$ of the world's total (Williams, 2004). The Nigerian fishery industry is made up of three sub-sectors. These are the artisanal, the industrial and aquaculture. The major culture species include, tilapia, carp and catfish. Catfish (African catfish) has a high growth rate and is highly appreciated in Nigeria (Livestock and Aquaculture Watch, 2007).

There is an increasing awareness for aquaculture in Nigeria. This has led to an increase in the turnout of the aquaculture industry. This boom in the industry has led to an increase in demand for Clarias gariepenus (Catfish), which is the major farmed specie. Yet the importation of frozen fish plays a key role in bridging the gap between the demand for and the supply of fish from domestic sources. The major species imported are Sadinnela eba (sardines), Mackerel spp (Mackerel) and Hake (Panla/ Stock fish).

An increase in production of the farmed specie is expected to have some negative externalities on the demand for the imported ones. This has implications for the management of fisheries as fish farms that are currently viable may become unviable if prices and revenue fall (Zabala, 1998). An idea about the substitutability possibilities between the farmed specie and the imported species is important and vital in the development of effective fishery management policies in Nigeria.

Based on the economic tenets of demand and supply; it is known that several factors influence the consumer's choice or demand for a particular product (e.g. colour, size, price, trade restrictions .etc ). These factors help to describe inter product price relationship showing the rate of increase or decrease in price or supply or demand of a product based on fluctuations in the demand for another product. The demand for fish is estimated at 1.55million tonnes. Of this estimated demand, domestic production caters for 511,000 tonnes and the remaining is taken care of by importation and aquaculture. Nigeria is one of the largest importers of fish with official records indicating an average of 560,000 tonnes annually. This was estimated at N30 billion (\$US400 million) in 2002 (Presidential Forum, 2005).

Aquaculture is about a century old in Africa. The yield from this sub sector in Africa has remained low over the years despite the vast potentials in the continent. (Jamu and Ayinla, 2003; Machena and Moehl, 2001). Nigeria is 
the largest culture fish producer in Africa with production ranging from 17,700 to 25,000 metric tonnes. (Machena and Moehl, 2001; Ridler and Hishamunda 2001).

\subsection{The Problem Statement}

Nigeria is endowed with many large rivers, man-made lakes, creeks and about 200 nautical miles of marine water under the Exclusive Economic Zone (EEZ). The Fishery industry has, however, not attained the desired level of self-sufficiency in fish production in Nigeria. The problem is that total domestic fish production is far less than the total domestic demand. The fear is that the unsatisfied demand will continue to be met through importation unless policy actions are geared towards improving domestic production in a sustainable way through aquaculture (Rahji et al; 2001)

In addition to this, the fishery resources of the country are far from being fully utilized. According to Olomola (1991), a review of aquaculture in Nigeria showed that only infinitesimal proportion of the resources available were being utilized. It is believed that the desire of drastically reducing fish importation can be attained through the harnessing and exploration of the existing potentials (Rahji et al; 2001).

A Survey by the Federal Fisheries Department (1986) showed that 65,000 hectares of brackish water resources and 4,000 hectares of fresh water aquaculture potential were yet to be utilized. In addition to this, private land resources, whose opportunity cost is zero because they are lying fallow, but can be used for fish farming, are many in Nigeria. There exists the possibility of putting over 160,000 hectares of land into fish farming. More so, fish fry production, especially of Tilapia, Heterotis, Clarias and Carp Fingerlings among others has been mastered in the country.

According to Zango Daura (2000), Nigeria’s importation of fish is worth 12 billion annually. The country is known to require 750,000 tonnes of fish per year. Domestic production amounts to 350,000 tonnes while importation makes up the balance of 400,000 tonnes. There is the research need, therefore to confirm whether or not consumers in Nigeria consider the farmed and imported species as close substitutes. If affirmatively confirmed, then trade restriction in the importation of fish and the encouragement of local production of fish will be beneficial to the economy. This constitutes the justification for embarking on the current study. The current import dependent situation is deemed to be unfavourable and non-optimal to the Nigerian economy and remains unacceptable in view of the natural fish habitat endowment of the country. There is the need to reduce the nation's dependence on fish imports.

In 1986, about 72 percent of total contribution to fish demand came from the artisanal sector. Import accounted for only about 18 percent. Industrial and aquaculture provided 7 and 4 percent respectively (Rahji et al; 2001). Over the years, the artisanal, industrial and aquaculture sub sectors have not reached their 1986 levels. They have experienced a decline such that they averaged 50,6 and 3 percent respectively by 1997. The importation of fish, from an all time low of about 18 percent in 1986, average about 42 of total demand by 1997. The same trends continue even today.

Yet, according to Olomola (1991), Nigeria has a great potential to increase the availability of fish by supporting and expanding aquaculture and as noted by Idachaba (1991), the fishery sub-sector performed below expectation in large part due to the over-reliance on imported inputs.

The problem focus of this study is on the possible effects of fish imports on the economy of Nigeria. These are in terms of the foreign exchange components and its drain on the foreign reserves, and the loss of employment opportunities for Nigerians especially the rural people thus aggravating their poverty level. Amao et al; (2007) asserted that there is overwhelming evidence that aquaculture benefits the poor in important ways. The poor derive a relatively large share of their income from it and there is the loss of the comparative cost advantage benefits of local production.

\subsection{Conceptual Framework}

What is a market?

A market is generally believed to be a point or avenue for buying and selling, a place where demand and supply forces interact. These interactions determine the market price and quantity of the product. Pairs or sets of goods would fall under the same market and interact amongst themselves based on how close they are in terms of the satisfaction derived from them by the consumers i.e. how substitutable they are.

Asche et al; (1997) described a market based on microeconomic theory as being defined over a set of commodities; and that these commodities interact and compete with each other in the same market based on 
consumer preferences. This competition is measured in cross price elasticities. These elasticities are an indication of the degree of substitution that exists between the commodities.

To determine the degree of substitution between commodities, the market delineation method of analysis is used. This technique can be used for products where, the more data intensive structural demand analysis is impossible and where data limitations are pronounced. Asche et al; (2004) explained that market prices are often available and easier to obtain, while the necessary data to generate good estimates of the demand equation are hard to find.

\subsection{Market and Market Delineation}

It is assumed generally that when prices of commodities in the same market are examined there is a certain pattern or trend by which these prices move in time. This trend is not magnitude dependent and might even change in the short run causing variations in prices to differ but in the long run the trend is re-established. The fact that prices are in dynamism, makes the use of traditionally econometric approaches not viable to explain market relationships (Asche et al; 2004).

Stigler and Sherwin (1985) stated that two products are considered to be in the same market if they are close substitutes and the relative prices maintain a stable ratio. Dickey et al; (1991) explained that the dynamism in the prices of commodities or time series has generated series of econometric problems. According to them, the economic theory suggests that some variables cannot wander far away from each other. If these time series are individually integrated of order one then they may be co integrated, and if this state exists between these variables then they would not wander far away from each other.

The question this poses is that does the absence of this relationship (co integration) mean that there are no long-run relationships between these variables even if there is an economic theory to back up a logical relationship? They answered this by saying that co integration is actually the evidence of a stable linear relationship. The lack of it does not imply, no stable long-run relationship but lack of any stable long-run linear relationship amongst the variables.

Zabala (1998), highlighted the history of the market delineation methodology beginning with Stigler and Sherwin (1985), who tried to analyse price similarities based on the correlation coefficients of prices, Horowitz (1981) who proposed a lagged price model to eliminate the disequilibrium price differences. This model was based on stable price differences between markets and unnecessary restrictive adjustment mechanism for temporary price shocks. This restriction formed the basis for criticisms of this method.

According to Zabala (1998), these early attempts at defining a market in terms of price had shortcomings. These were: prices are usually subjected to common influences. These influences (like inflation) could lead to high correlation coefficients thereby leading to the wrong conclusion that there is the existence of a single market. A subjective correlation is needed to define markets and correlation coefficients are not able to account for the long-run price responses. High correlation coefficients can also be obtained by chance due to coincidence among price movements of goods that are clearly not in the same market.

\subsection{Market Delineation in Fisheries}

Perez-Agundez et al; (1999) tested for the existence of long-run relationships for hake between different auction markets in the French hake market. Using multivariate co integration analysis, they were able to identify at least seven potential regional groupings of the auction markets but were unable to identify a common market. They were able to ascertain that the markets were being driven by an 'attractor'. This implies the force driving the markets to the long-run relationship/equilibrium. This 'attractor' could be a dominant national market which would mean that there is a separate French hake market. This 'attractor' could be an international driver market. This could mean that the French market is a part of an international market.

Jaffry et al; (2005) studied the Spanish market. This was analysed using market delineation methodology. They used the Johansen Multivariate approach to deduce the long-run relationship vectors. They found out that increased consumption of salmon in Spain had not been at the expense of other species. They surmised that the scale flexibilities suggested that fish is a luxury good although some species like hake, cuttlefish, squid and tuna maybe considered as necessities in the Spanish market.

Jaffry et al; (1999) examined the long-run price flexibilities for four highly valued U.K fish species namely bass, lobster, sole and turbot using the multivariate technique. Estimates for the long-run relationship between fish prices and landings were obtained. The analysis showed that, there was more than one co integration vectors among the variables. It also showed that bass had the largest absolute long-run price flexibility. Bass and lobster were found to be weak substitutes. Sole and turbot were found to be close substitutes although the results showed that the substitution is unidirectional and not symmetrical. 
Vassdal and Sirnes (2000) concentrated on the effect of the structural break in the relationship between the price of the Norwegian Salmon exported to the EU and the Chilean Salmon exported to the US. Co integration analysis showed that there was a long-term relationship between the price of Salmon in the EU and in the US before and after the structural break. The result led to policy restrictions on the price and quantum of Norwegian Salmon.

Hartman et al; (2000) examined the relationship between hake prices at different levels along the value chain in the French market. They used a combination of co integration analysis with the Law of One Price test (LOP) to generate long-run relationships and to find the mark ups along the value chain. They found that there was a relationship between prices for whole fresh hake at the auction and wholesale and retail levels on the value chain. However, the LOP tests showed that there was no proportionality between the wholesale and retail level, or between the auction and retail level.

\subsection{Co integration: Theoretical / Analytical Framework}

Co integration is the phenomenon where two or more unit root processes (non-stationary) have linear combinations, which are stationary. These linear combinations are interpreted as long-run relationships (Bierens 2005). This phenomenon has become a very common tool or technique in market delineation studies (Perez-Agundez et al, 1999; Goodwin and Schroeder, 1991; Stock and Watson, 1988; Jaffry et al, 2005).

Careful statistical analysis of the dynamic interactions between and among series requires an assessment of whether the series are mean and variance stationary. Standard statistical and econometric techniques are generally valid only when working with stationary variables. If these techniques are applied to non stationary series, spurious correlations and regressions are likely to result. Non stationarity in the mean of these price series can be caused by deterministic time trends, stochastic time trends or unit roots, and/or structural breaks in the underlying determinants of prices. Series that are stationary in levels, without the need to first-difference them, are said to be $\mathrm{I}(0)$ or integrated of order zero. Series that must be first-differenced to render them stationary are said to be I(1), integrated of order one. Equivalently, they contain a (single) unit root. In sum, if prices are I(1), testing for the presence of co integration and then estimating an Error Correction Model (ECM), which provides an estimate of the speed of adjustment toward the long-run equilibrium, seems to be a very natural way to proceed. Indeed it is difficult to think of a superior approach for assessing the geographic extent of the market using only information on prices.

\subsection{Co integration methodology}

With the advent of time series or variables that exhibit Brownian motion, traditional econometric methods do not seem to be able to adequately estimate a non- biased or good model. The issue of spurious regression became the only result that could be achieved when non-stationary data are regressed on one another. (Granger and Newbold, 1974, Hendry, 1980)

Co integration is the stable long-term linear relationship between two unstable time series and it is related to common trends (Johansen 1988). It is common knowledge that the variables would suffer shocks and forces within the system which would pull them apart but in the long run if they are co integrated they would comeback together sort of like reverting back to the long-run equilibrium. (Engle and Granger, 1991).

\subsection{Objectives of the Study}

The general objective of this study is to define the fish market in Nigeria through the application of the co integration methodology. The specific objectives include to:

1.carry out an overview of the aquaculture fishery industry in Nigeria,

2. test for stationarity or otherwise in the price series of the species

3. determine whether consumers consider the local specie and the imported species as close substitutes.

4. ascertain whether culture fish is in the same market as the imported species, and

5. determine the speed of adjustment between the price of the farmed specie and the prices of the imported species.

\section{Methodology}

\section{(i) Data Sources}

The data were for a period of 1970 to 2005. Data were on the yearly prices for 36 years. The data set consists of prices for four fish species catfish (Cat), hake (Hak), mackerel (Mac) and sadinnela (Sad). In this analysis, catfish is the culture specie and the others are the imported species. The data for this study were sourced from the 
Federal Office of Statistics, Federal Department of Fisheries, Ministry of Agriculture, National Institute of Freshwater Fisheries, and National Institute of Marine Research.

\section{(ii) Methods of Data Analysis}

(a) Test of Stationarity of Variables

The Augmented Dickey Fuller (ADF) test used and it is based on the following specification

$$
\Delta \mathrm{X}_{\mathrm{t}}=\text { ao }+\beta \mathrm{X}_{\mathrm{t}-1}+\sum_{t=1}^{4} \sigma \Delta \mathrm{X}_{\mathrm{t}-1}+\varepsilon_{\mathrm{t}}
$$

The ADF test controls for higher-order correlation by adding lagged difference terms of the dependent variable to the right hand side of equation (1). All the prices were expressed in natural logarithms. The lags or lag length included was determined by the Akaike Information Criterion(AIE). It was found to be four for all the series. Based on the suggestion by Dickey et al; (1986), Miller and Russek, (1990), the ADF equations were estimated with an intercept and no time trend. The test was carried out both at the levels and first difference. The hypothesis tested for the variable $\left(X_{t}\right)$ is Ho: $\beta=0$ for non stationarity and Ho: $\beta<0$ for stationarity

(b) Test of Co integration: Johansen`s Bivariate and Multivariate Tests

These tests were used subject to the confirmation that the series are stationary in first difference i.e. I(1). The Johansen`s maximum likelihood procedure was based on the following vector error correction representation

$$
\Delta Z_{\mathrm{t}}=\Sigma \text { aj } \Delta \mathrm{Z}_{\mathrm{t}-\mathrm{j}}+\Theta(\mathrm{r}) \mathrm{Z}_{\mathrm{t}-\mathrm{j}}+\text { et }
$$

The $Z_{t}$ is the $2 x 1$ vector of $I(1)$ processes. The rank of $\Theta(r)$ equals the number of co integration vectors. This is tested using the maximum eigen value and trace statistics. The critical values are taken from Johansen and Juselius (1992).

The bivariate co integration test developed by Engle and Granger (1987) is based on the stationarity of the residuals of the co integrating equations. The three equations Cat and Hak, Cat and Mac and Cat and Sad were estimated. Their reversed-forms Hak and Cat, Mac and Cat and Sad and Cat were also estimated. The paired prices are co integrated if the residuals of their forward and reversed equations are both stationary. This means that there is a common stochastic trend between them that makes it unlikely for them to deviate from each other without bound.

The co integrating equation for Cat and Hake for instance is

$$
\mathrm{Cat}_{\mathrm{t}}=\mathrm{q}_{\mathrm{o}}+\mathrm{q}_{1} \mathrm{Hak}_{\mathrm{t}}+\mathrm{U}_{\mathrm{t}}
$$

(c) Test of Residuals

Following Gujarati (1999), the ADF test for the residuals in the bivariate test was carried out in the form

$$
\Delta \mathrm{U}_{\mathrm{t}}=-\lambda \mathrm{U}_{\mathrm{t}-1}
$$

According to Gujarati (1999), there is no need to introduce intercept and trend variable in the regression.. However, the $-\lambda$ parameter must be significantly different from zero. If the coefficient is statistically significant, it could be concluded that Cat responds to disequilibrium in the Cat- Hak relationship.

If the two variables (prices) are $\mathrm{I}(1)$ from the $\mathrm{ADF}$ tests and the residuals are $\mathrm{I}(0)$ from the residual tests, they are said to be co integrated. This means that there is a long-run or equilibrium relationship between the pairs. The regression analysis involving them will also not be spurious (Mohanty et al; 1996).

(d) The Error Correction Model (ECM).

Co integration is a necessary and sufficient condition for the representation of the series in an ECM (Engle and Granger, 1987). The ECM model was estimated for the three pairs of prices using the specification below

$$
\Delta \mathrm{Cat}_{\mathrm{t}}=\mathrm{A}+\Sigma \mathrm{bi} \Delta \mathrm{Cat}_{\mathrm{t}-\mathrm{i}}+\Sigma \mathrm{dj} \Delta \mathrm{W}_{\mathrm{t}-\mathrm{j}}+\gamma \mathrm{U}_{\mathrm{t}-\mathrm{i}}
$$

Where $i=1,2,3,4 . \quad j=1,2,3,4$. and $\quad W$ can represent Hak, Mac or Sad as the case may be.

The residuals $\left(\mathrm{U}_{\mathrm{t}}\right)$ are the error correction terms and they represent the departure from the long-run equilibrium between the variables. The size and statistical significance of the coefficient on the error term $(\gamma)$ measures the tendencies of each variable to return to equilibrium. A significant coefficient implies that past equilibrium errors play a role in determining the current outcomes. The short-run dynamics are captured through the individual coefficients of the differenced terms. 


\section{Results and Discussion}

\subsection{Aquaculture Projects and Government Policies in Nigeria: An Overview}

Aquaculture projects in Nigeria have a chequered history dating back to the 1950's. The first project was commissioned by the British Colonial government in 1954 in Payan, near Jos, Plateau State. This was followed by the one in Maska, in Funtua district of Katsina, Katsina state; Agodi farms in Ibadan, Oyo state; and Umuna farms in Okigwe, Imo state \{Nigeria Institute of Freshwater Fisheries Research (2000).

The Federal Ministry of Agriculture through its agencies, Federal Department of Fisheries, Nigeria Institute of Oceanography and Marine Research (NIOMR) and Nigeria Institute of Freshwater Fisheries Research, River Basin Development Authorities and the proscribed Directorate of Food, Road and Rural Infrastructure (DFFRI), established several aquaculture projects. These include the ones in Olupona, Osun State; Lafiaji, Plateau State; Makurdi, Benue State; Enugu - Aboh, Enugu State; Dwam, Adamawa State; Mando, Kaduna State; Wuya, Niger State; Oyo, Oyo state; Zuru, Sokoto State; Ilenuwa, Ogun State; Sepeteri, Oyo State; Igede, Ekiti State; New Yidi, Kwara State; Eziullo, Anambra State, and Gubi, Bauchi State (Adikwu, 1999).

The eleven River Basin Development Authorities in the country constructed fifty-three dams, each with varying degree of potential for fish farming. Among these dams are Tiga dam/fishery scheme in Kano State with water storage capacity of 1.82 billion litres and surface area of 76 square kilometers, Kangimi dam/fishery scheme in Kangimi local government area of Kaduna state; Kainji lake/fishery scheme and Edozligi dam/fishery scheme in Edozligi Local Government Area of Niger state. Others are Oyan, Shiroro, Bakolori, and Katsina dam/fishery schemes etc.

The proscribed DIFFRI also established several hatchery centres across the nation propagating and supplying adequate and economically viable fry and fingerlings for aquaculture development (Okuneye, 1986, Federal Department of Fisheries, 1991). These agencies emphasized the important role of fish production as a strategy for addressing fish scarcity. They provided technical support for aquaculture projects and extension services to the coastal artisanal fishing communities. Yet, the case for rural aquaculture in Nigeria where there exist extensive fresh, brackish and marine water is still undeveloped. This could provide the means of reducing the continued depletion of the wild and of enhancing fish production and income generation.

Fadama areas are particularly suited for aquaculture for various reasons. This includes the fact that most are located in rural areas. These areas have relatively high water tables thereby making water extraction for fish farming relatively cheap. Intensive and semi-industrial aquaculture are capital intensive and success depends mainly on management practices. Intensive and semi-intensive production in ponds provides a reliable income and assured profit. Various profitable production systems are available in aquaculture. The option employed may be a monoculture system whereby single specie is stocked or polyculture where two or more complimentary species are stocked. A successful aquaculture programme for the rural communities has major benefits for the welfare of the rural dwellers in terms of providing: additional income, much needed animal protein, improved nutrition and health and social wellbeing.

Ridler and Hishamunda (2001) highlighted the advantages of aquaculture in Sub-Saharan Africa mentioning that it relies on private funds instead of public funds and that it would stimulate the advancement of technology while being sustainable subject to good management. They further pointed out that there was a lot of opportunities for the sector to thrive as there was growing shortage of fish for domestic markets, suitable land resource amongst other factors; but they added that across the continent factors like limited access to credit facilities shortages and high cost of feed could restrict the growth and development of this sub sector.

Jamu and Ayinla (2003) suggested that for the sector to realise its full potential it was necessary to promote policy research on how aquaculture production can respond to changing macroeconomic policies; develop management technologies that would aid production of indigenous species for local markets. It can provide an avenue to bridge the ever-widening gap between demand and supply of fish products. It will be able to make use of land resources that would have otherwise been a waste to agriculture (e.g. swamps etc). It can open up an avenue for foreign exchange earnings and provision of employment for the people of the country (Presidential Forum 2005)

The aquaculture sub-sector can be divided into Extensive, Semi-Intensive and Intensive aquaculture system. This is dependent on the level of technology and interference or control of the natural habitat and life cycle of the fish resource. The country is currently producing $1 \%$ of its estimated potential. This has translated to $6 \%$ of the domestic fish production. Factors such as inadequate supply of fingerlings, insufficient supply of quality fish feed, inadequate facilities for genetic improvement, disease identification and control coupled with inadequate 
baseline data for planning and research have hampered the development of aquaculture in Nigeria. This overview captures the essence and the achievement of the first objective of this study.

The results of the Augmented Dickey - Fuller (ADF) tests are presented in. Table1. Based on the critical values reported by Mackinnon (1996), all the price series appeared not to be stationary in their levels. The null hypothesis of non-stationary was not rejected for the price in levels. This hypothesis was, however, rejected for all the prices in first difference. Hence, the price series were found to be stationary in first differences. So the second objective of the study is attained.

In Table 2, the Jarque - Bera statistic was used to test the residuals of the series to see whether they are normally distributed or not. The test proved that they are normally distributed. Hence, the null hypotheses of normality cannot be rejected at the 5\% level of significance. The series are therefore 1(1) and so are integrated of order one.

Table 3 shows the results of the Johansen multivariate test for the price series. The LR test based on the trace and max-eigen value tests reject the null hypothesis up to $r \leq 2$ at the $1 \%$ level and up to $r \leq 3$ at the $5 \%$ level. The trace test indicates 4 co integrating equations at the 5\% level and 3 co integrating equations at the $1 \%$ level. Similarly, the max-eigen test indicates 4 co integrating equations at the $5 \%$ level and 3 co integrating equations at the $1 \%$ level. The tests indicate four integration vectors and hence one common stochastic trend in the system This finding tends to suggest that there is one market for the species (local and imported). This means that all the species are substitutes for one another. In this instance the imported species substitute for the farmed or local specie. By so doing, the third objective is achieved.

In Table 4, both the trace and eigen value tests reject the null hypothesis of no co integrating vectors $(r=0)$ at the $5 \%$ significance level. The tests failed to reject the null hypothesis of one or fewer co integrating vectors $(\mathrm{r} \leq$ 1). Hence, the results from the Johnasen`s multivariate (Table 3) and bivariate (Table 4) approaches indicate that the development of price for the different species seem to be well integrated in the long - run (Asche et al; 1999).

This section presents the results of the co integration analysis for the six pairs of the price variables. The forward regression results are reported in Table 5 while the reversed regression results are contained on Table 6 . The ADF test statistics on the residuals are presented in the last column of Table 6. Using these values in conjunction with the critical Mackinnon statistics at $1 \%$ of $-2.6308,5 \%$ of -1.9504 , and $10 \%$ of -1.6112 , the non-stationarity of the residuals is rejected at the $5 \%$ and $10 \%$ significance levels in all cases and at $1 \%$ significance level in four cases. It is theoretically plausible and reasonable to conclude that the pairs of price series in the estimated equations are cointegated. This implies that a long-run equilibrium relationship also exists between these pairs of price series.(Engle and Granger, 1987). An economic interpretation of this finding is that there is some factor (substitution or arbitrage) that binds the prices together over time. In the words of Slade (1986), the species in question are within the same market boundaries. (Asche et al; 1999 ). This finding helps in meeting the fourth objective of this study.

Table 7 presents the OLS results of the estimated ECM equations. The ECM was estimated for each pair of co integrated price series for the local specie and the imported species. Residuals of the cointegration equations were lagged and used as the error correction terms in the ECM equations.

The main finding from the results is that the error correction or disequilibrium terms are found to have statistically significant coefficients. This suggests that the price of catfish adjusts to correct for long-run disequilibrium in the prices of the imported species. These results also indicate that the price of catfish is not insulated from the prices of the imported species. The prices of the imported species are however insulated from the price of the local species. Thus, fish production policies, designed to alter fish prices without taking into account the prices of the imported species are not likely to be effective in Nigeria. The error correction model was also estimated to gauge the speed of adjustment towards equilibrium. The error correction term captures the changes in the dependent variable required to eliminate past departure of actual values of the prices from the equilibrium levels.

The speed with which the model converges to equilibrium is shown by the ECM coefficients. The results show that the coefficients of ECM (-1) are $-0.2642,-0.2403$ and -0.2531 respectively for the estimated equations. They are properly signed and are significant at the $5 \%$ level. This indicates that the adjustment to restore the long-run relationship is in the right direction. The magnitude of the ECM (-1) is lowest in the Cat-Mac equation $(-0.2403)$. This is higher in the Cat-Hak and Cat-Sad equations. The coefficients of the error correction terms which are the speed of adjustment of the dependent variable to the independent variables can be represented in percentages as 26.42, 24.03 and 25.31. This measures the percentage deviation from the dependent variable that is corrected 
each year by movement in the independent variables. This indicates that the speed of adjustment is lowest in the Cat-Mac equation followed by Cat-Sad and Cat-Hak in that order. In this way, the fifth objective of this study is met.

\subsection{Policy Implication of the Study}

The policy implication of this study is that the price of catfish is not insulated from the prices of the imported species. The prices of the imported species are however insulated from the price of the local species. Thus, fish production policies, designed to alter fish prices without taking into account the prices of the imported species, are not likely to be effective in Nigeria. An effective policy will be one that will drastically reduce the local production costs of farmed fish in Nigeria such that the marginal cost of production in Nigeria vis-a vis the marginal costs of producing the imported species favours the local producers / farmers. In other words, the local marginal costs should be far lower than their foreign counterparts. In this way, the farmed specie will be cheaper to the consumers and this will discourage fish importation.

\section{References}

Adikwu, I. A. (1999). Aquaculture in Nigeria: Prospects and Constraints. Journal of Fisheries Technology, Vol. I (1), New Bussa, Niger State, Nigeria. Federal College of Fresh Water Fisheries Technology. Pp. 16 - 25.

Asche, F., \& Salvanes, G. (1997). Database: Business Source Premier0002-9092. American Journal of Agricultural Economics, Vol. 79(1).

Asche, F., \& Steen, F. (1998). The EU fish market, SNF report XX/98. FAIR project CT96-1814 DEMINT.

Asche, F., Gordon, D., \& Hannesson, R. (2004). Tests for the Market Integration and the Law of One Price: The Market for Whitefish in France, Marine Resource Economics, Vol. 19.

Bierens, H. J. (2005). Econometric Analysis of Linear zed Singular Dynamic Stochastic General Equilibrium Models. [Online] Available: http://www.econ.psu.edu/ hbierens/SDSGEM.PDF. (October 12, 2006).

Engle, R. F., \& Granger, C. W. J. (1987). Co-integration and Error Correction: Representation, Estimation and Testing. Econometrica, 55, 251-76.

Federal Department of Fisheries. (1988). Annual Report. Lagos, Nigeria.

Federal Department of Fisheries. (2000.). Annual Report. Abuja, Nigeria.

Federal Department of. Fisheries. (1991). Annual Report.Wuse Zone 1, Abuja, Nigeria. Pp. 1 - 24.

Federal Department of. Fisheries. (1986). World Bank Review Study of Nigeria Fisheries. CARD: Department of Agricultural Economics, University of Ibadan. Nigeria

Goodwin, B. K., \& Schroeder, T.C. (1991). Cointegration Tests and Spatial Price Linkages in Regional Cattle Markets. American Journal of Agricultural Economics, 73(2), 452-464.

Granger, C. W. J. \& Newbold, P. (1974). Spurious Regressions in Econometrics. Journal of Econometrics, 26, 1045-1066.

Gujarati, D. N. (1999). Basic Econometrics. (4 ${ }^{\text {th }}$ Ed).: Singapore. McGraw-Hill.

Harris, R.I.D. (1995). Using Co intergration Analysis in Econometric Modelling. Hemel Hempstead: Prentice Hall/ Harvester Wheatsheaf.

Hendry, D.F. (1980). Econometrics-Alchemy or Science? The London School of Economics.

Horowitz, I. (1980). Market Definition in Antitrust Analysis: A Regression-Based Approach. Southern Economic Journal, 48:1-16.

Idachaba, F.S. (1991). The Nigerian Food Problem. Journal of Agriculture, Science and Technology, Vol. 1(1) : 5- 16 June, 1991

Irz, X; Stevenson, J.R; Tanoy, A; Villante, P. and Moressons, p. (2007). The Equity and Poverty Impacts of Aquaculture: Insights from the Phillipines. Development Policy Review, 25(4): 495-594

Livestock and Aquaculture Watch. (2007). Fishing Boom in Nigeria. The Monthly Journal for Livestock and Aquaculture Business, Vol. 2(11): 6. [Online] Available: www.livestockaquaculture.com

Jaffry, S., Taylor, G. and Pascoe, S. (2005). An inverse demand system for fish species in Spain. CEMARE Working Paper No: 2, Centre for Economics and Management of Aquatic Resources (CEMARE), University of Portsmouth. 
Jaffry, S., Taylor, G., Pascoe, S., and Zabala, U. (1998). Market delineation of fish in Spain. CEMARE research paper No: 140, Centre for Economics and Management of Aquatic Resources (CEMARE), University of Portsmouth.

Jamu, D.M., \& Ayinla, O.A. (2003). Potential for the development of aquaculture in Africa. NAGA World Fish Centre, 26(3), Jul-Sept.

Johansen, S., \& Juselius, K. (1990). Maximum likelihood estimation and inference on cointegration - with application to the demand for money, Oxford Bulletin of Economics and Statistics, 52, 169-210.

Machena, C., \& Moehl, J. (2001). Sub-Saharan African aquaculture: regional summary.Techincal Proceedings of the Conference on Aquaculture in the Third Millennium Bangkok, Thailand, 20-25 February (2000) pp 341-355 NACA Bangkok and FAO, Rome.

Mohanty, S; E. Wesley; F. Peterson and D.B. Smith. (1996). Relationships Between U.S and Canadian Wheat Prices: Cointegration and Error Correction Approach. Canadian Journal of Agricultural Economics, 44: 265 276.

Nigeria Institute of Fresh water Fisheries research. (2000-1). Fish Farming in Nigeria. News Letter Vol 17, New Bussa, Niger State, Nigeria. Nigeria Institute of Fresh Water Fisheries Research. Pp. 1 - 3.

National Population Bureau. (1987). Nigeria Population Census. Lagos, Nigeria

Okuneye, P. A. (1986). Enhancing Fisheries Development in Nigeria: The Case of River Basin Development Authority. Journal of West Africa Fisheries, Vol. 1 (1) Pp. 55-63.

Olomola, A.S. (1991). Capture Fisheries and Aquaculture in Nigeria: A Comparative Analysis. ARSSRN, Winrock International, USA.

Perez-Agundez, J. A. P., Taylor. G., Jaffry, S., Bailly D. (1999). The Spatial Delineation Of the French Hake Market. Paper presented at The XI ${ }^{\text {th }}$ Conference of the European Association of Fisheries Economists, Dublin 6-10 April (1999) and economic review, 6(2).

Presidential Forum on Fisheries and Agriculture: Status and Opportunities. (2005). Abuja, Nigeria.

Rahji, M.A.Y; Popoola, L; and L.A. Adebisi. (2001). Analyses of the Demand for and Supply of Fish in Nigeria 1986-1997. Journal of West African Fisheries, Vol. 10 : 543-550

Ridler, N. \& Hishamunda, N., (2001). Promotion of sustainable commercial aquaculture in sub-Saharan Africa. Policy framework. FAO; Rome 1.67pp.

Slade, M. E. (1986). Exogeneity Test of Market Boundaries Applied to Petroleum Products. Journal of Industrial Economics. 34:291-304.

Stigler, J. \& Sherwin, R. A. (1985). The Extent of the Market. Journal of Law and Economics, 28, 555-585.

Stock, J. H., \& Watson, M. W. (1988). Testing for Common trends. Journal of American Statistics Association, 83:1097-1107.

Vassdal, T., \& Sirnes, E. (2000). Structural breaks in the European and US market for Salmon. University of Tromso. Norwegian College of Fishery Science.

Zabala, U. (1998). Price linkages in the Spanish Fish Market: a multivariate co intergration approach University of Portsmouth.

Zango-Daura, S. (2000). Fish Import Gulps N12 billion Yearly. New Nigerian Newspaper, Monday $22^{\text {nd }}$, May, 2000 Pg. 1.

Table 1. The Results of the Unit Root Tests for the Prices

\begin{tabular}{|l|l|l|}
\hline Variable & $\begin{array}{l}\text { ADF t- Statistic } \\
\text { Levels }\end{array}$ & $\begin{array}{l}\text { ADF t- Statistic } \\
\text { First Difference }\end{array}$ \\
\hline LnCat & -0.2538 & -5.7634 \\
\hline LnHak & -0.3420 & -4.5052 \\
\hline LnMac & -0.3956 & -3.7700 \\
\hline LnSad & -0.5033 & -3.9478 \\
\hline
\end{tabular}

Source: Data Analysis, 2009. 
Table 2. Test of Normality Distribution of the Series of Prices

\begin{tabular}{|l|l|l|l|l|}
\hline Item & Cat & Hak & Mac & Sad \\
\hline Jarque-Bera & 7.6812 & 9.5348 & 8.1204 & 7.7844 \\
\hline probability & 0.0215 & 0.0085 & 0.0173 & 0.0204 \\
\hline
\end{tabular}

Source: Data Analysis, 2009.

Table 3. Results of the Multivariate Johansen Test of the Series of Prices

\begin{tabular}{|l|l|l|l|l|l|l|l|}
\hline Ho & $\mathrm{H}_{1}$ & Max-Eigen & $\begin{array}{l}\text { Critical } \\
\text { value 1\% }\end{array}$ & $\begin{array}{l}\text { Critical } \\
\text { value 5\% }\end{array}$ & $\begin{array}{l}\text { Trace } \\
\text { statistics }\end{array}$ & $\begin{array}{l}\text { Critical } \\
\text { value 1\% }\end{array}$ & $\begin{array}{l}\text { Critical } \\
\text { Value 5\% }\end{array}$ \\
\hline $\mathrm{r}=0$ & $\mathrm{r}=1$ & $79.3797^{* *}$ & 28.82 & 23.80 & $159.4762^{* *}$ & 45.58 & 39.89 \\
\hline $\mathrm{r} \leq 1$ & $\mathrm{r}=2$ & $49.9854^{* *}$ & 22.99 & 17.89 & $80.0965^{* *}$ & 29.75 & 24.31 \\
\hline $\mathrm{r} \leq 2$ & $\mathrm{r}=3$ & $25.6870^{* *}$ & 15.69 & 11.44 & $30.1111^{* *}$ & 16.31 & 12.53 \\
\hline $\mathrm{r} \leq 3$ & $\mathrm{r}=4$ & $4.4241^{*}$ & 6.51 & 3.84 & $4.4241^{*}$ & 6.51 & 3.84 \\
\hline
\end{tabular}

$* *$ denotes rejection of the null hypothesis at $1 \%$

* denotes rejection of the null hypothesis at $5 \%$

Source: Data Analysis, 2009.

Table 4. Results of the Bivariate Johansen Tests for the Price Pairs

\begin{tabular}{|l|l|l|l|l|l|l|}
\hline Variable & Ho & $\mathrm{H}_{1}$ & $\begin{array}{l}\text { Trace } \\
\mathrm{t} \text {-stat }\end{array}$ & $\begin{array}{l}\text { Critical } \\
\text { value }\end{array}$ & Max-Eigen & $\begin{array}{l}\text { Critical } \\
\text { value }\end{array}$ \\
\hline Cat-Hak & $\mathrm{r}=0$ & $\mathrm{r}=1$ & $18.3182^{*}$ & 12.53 & $13.4236^{*}$ & 11.44 \\
\hline & $\mathrm{r} \leq 1$ & $\mathrm{r}=2$ & 2.7266 & 3.84 & 2.7266 & 3.84 \\
\hline Cat-Mac & $\mathrm{r}=0$ & $\mathrm{r}=1$ & $13.4769^{*}$ & 12.53 & $12.5119^{*}$ & 3.84 \\
\hline & $\mathrm{r} \leq 1$ & $\mathrm{r}=2$ & 0.0334 & 3.84 & 0.0334 & 3.84 \\
\hline Cat-Sad & $\mathrm{r}=0$ & $\mathrm{r}=1$ & $20.6533^{*}$ & 12.53 & $13.1319^{*}$ & 11.44 \\
\hline & $\mathrm{r} \leq 1$ & $\mathrm{r}=2$ & 0.0035 & 3.84 & 0.0035 & 3.84 \\
\hline
\end{tabular}

Source: Data Analysis, 2009.

Table 5. Results of the Forward Equations for the Price Pairs

\begin{tabular}{|l|l|l|l|l|l|l|l|}
\hline Equation & Constant & Hak & Mac & Sad & $\begin{array}{l}\text { Equation } \\
\text { p-value }\end{array}$ & Residuals & $\begin{array}{l}\text { Residuals } \\
\text {-value }\end{array}$ \\
\hline Cat & 0.0510 & 0.9854 & - & - & 0.0015 & $-2.0455^{* *}$ & 0.0406 \\
\hline & $(3.4451)$ & $(371.3393)$ & - & - & - & - & - \\
\hline Cat & 0.1779 & - & 0.9529 & - & 0.0003 & $-3.5122^{* * *}$ & 0.0009 \\
\hline & $(4.0277)$ & - & $(121.6867)$ & - & - & - & - \\
\hline Cat & 0.5266 & - & - & 0.9093 & $2.7 \mathrm{E}-09$ & $4.8428^{* * *}$ & 0.0000 \\
\hline & $(7.9047)$ & - & - & $(75.5654)$ & - & - & - \\
\hline
\end{tabular}

** indicates rejection of null hypothesis of non-stationarity of residuals at $5 \%$ level of significance

*** indicates rejection of null hypothesis of non-stationarity of residuals at $1 \%$ level of significance

All are integrated of order zero i.e. I(0)

Source: Data Analysis, 2009. 
Table 6. Results of the Reversed Equations for the Price Pairs

\begin{tabular}{|l|l|l|l|l|l|}
\hline Equation & Constant & Cat & $\begin{array}{l}\text { Equation } \\
\mathrm{p} \text {-value }\end{array}$ & Residuals & p-value \\
\hline Hak & -0.0504 & 1.0145 & $1.6 \mathrm{E}-06$ & $-2.0296^{* *}$ & 0.0421 \\
\hline & $(3.3304)$ & $(371.3393)$ & - & - & - \\
\hline $\mathrm{Mac}$ & -0.1741 & 1.0470 & $1.4 \mathrm{E}-04$ & $-3.4777^{* * *}$ & 0.0010 \\
\hline & $(3.6542)$ & $(121.6867)$ & - & - & - \\
\hline $\mathrm{Sad}$ & -0.5475 & 1.0930 & $2.3 \mathrm{E}-09$ & $-4.8486^{* * *}$ & 0.0000 \\
\hline & $(6.8344)$ & $(75.5654)$ & - & - & - \\
\hline
\end{tabular}

** indicates rejection of null hypothesis of non-stationarity of residuals at $5 \%$ level of significance

*** indicates rejection of null hypothesis of non-stationarity of residuals at $1 \%$ level of significance

All are integrated of order zero i.e. I(0)

Source: Data Analysis, 2009.

Table 7. Results of the Estimated Error Correction Models for the Price Pairs

\begin{tabular}{|c|c|c|c|c|c|}
\hline Variables & Cat-Hak & Variables & Cat-Mac & Variables & Cat-Sad \\
\hline$\Delta$ Cat(-1) & $-0.5769 * * *$ & $\Delta \operatorname{Cat}(-1)$ & $-0.2645^{* *}$ & $\Delta \operatorname{Cat}(-1)$ & $-0.2833 * * *$ \\
\hline & $(2.7256)$ & & $(2.2379)$ & & $(2.7659)$ \\
\hline$\Delta \operatorname{Cat}(-2)$ & $-0.4807^{* *}$ & $\Delta \operatorname{Cat}(-2)$ & $-0.2341^{* *}$ & $\Delta \operatorname{Cat}(-2)$ & $-0.2711)^{* * *}$ \\
\hline & $(2.3319)$ & & $(2.0206)$ & & $(2.9183)$ \\
\hline$\Delta \operatorname{Cat}(-3)$ & $-0.5827^{*}$ & $\Delta \operatorname{Cat}(-3)$ & -0.1863 & $\Delta \operatorname{Cat}(-3)$ & $-0.2127^{*}$ \\
\hline & $(1.6903)$ & & $(1.3342)$ & & $(1.7432)$ \\
\hline$\Delta \operatorname{Cat}(-4)$ & 0.2787 & $\Delta \operatorname{Cat}(-4)$ & -0.1475 & $\Delta \operatorname{Cat}(-4)$ & -0.3115 \\
\hline & $(0.3448)$ & & $(1.2119)$ & & $(1.5463)$ \\
\hline$\Delta \operatorname{Hak}(-1)$ & $0.2145^{* *}$ & $\Delta \operatorname{Mac}(-1)$ & $0.3215^{* * *}$ & $\Delta \operatorname{Sad}(-1)$ & $0.2471 * * *$ \\
\hline & $(2.1270)$ & & $(2.8170)$ & & $(2.8336)$ \\
\hline$\Delta \operatorname{Hak}(-2)$ & $0.2876^{* *}$ & $\Delta \operatorname{Mac}(-2)$ & $0.2314 * * *$ & $\Delta \operatorname{Sad}(-2)$ & $0.1545^{* *}$ \\
\hline & $(2.2543)$ & & $(2.6276)$ & & $(1.9873)$ \\
\hline$\Delta \operatorname{Hak}(-3)$ & 0.3271 & $\Delta \operatorname{Mac}(-3)$ & 0.2402 & $\Delta \operatorname{Sad}(-3)$ & 0.09653 \\
\hline & $(1.3642)$ & & $(1.1344)$ & & $(1.3427)$ \\
\hline$\Delta \operatorname{Hak}(-4)$ & 0.1295 & $\Delta \operatorname{Mac}(-4)$ & 0.3256 & $\Delta \operatorname{Sad}(-4)$ & 0.1522 \\
\hline & $(1.5336)$ & & $(1.3477)$ & & $(1.2748)$ \\
\hline $\mathrm{ECM}$ & $-0.2642 * *$ & ECM & $-0.2403 * *$ & ECM & $-0.2531 * *$ \\
\hline & $(2.4693)$ & & $(2.2395)$ & & $(2.3274)$ \\
\hline Constant & 1.2543 & Constant & 1.4021 & Constant & 1.3125 \\
\hline \multicolumn{3}{|c|}{0.6584} & 0.6710 & & 0.6493 \\
\hline
\end{tabular}

Source: Data Analysis, 2009. 